$\begin{gathered}\text { Науковий вісник НлтУ України } \\ \text { Scientific Bulletin of UNFU } \\ \text { http://nv.nltu.edu.ua }\end{gathered}$
$\begin{gathered}\text { https://doi.org/10.15421/40280322 } \\ \text { Article received 02.04.2018 p. } \\ \text { Article accepted 26.04.2018 p. } \\ \text { УдSN 1994-7836 (print) } \\ \text { ISSN 2519-2477 (online) }\end{gathered}$

Ф. Д. Матіко ${ }^{1}$, О. М. Слабик', М. Б. Гутник ${ }^{2}$

${ }^{1}$ Національний університет "Львівська політехніка", м. Львів, Україна

${ }^{2}$ Приватне акціонерне товариство "Інститут енергоаудиту та обліку енергоносї̈", м. Львів, Україна

\title{
АНАЛІЗ НОРМАТИВНОГО ЗАБЕЗПЕЧЕННЯ СИСТЕМ ВИМІРЮВАННЯ КІЛЬКОСТІ ТЕПЛОВОЇ ЕНЕРГІЇ
}

Теплову енергію широко використовують у промисловості та житлово-комунальному господарстві України. Налаго-
дження точного обліку теплової енергії (ТЕ) є необхідним для ії ефективного та економного використання, а також дає змо-
гу виявити недоліки теплогенерувальних об'єктів і теплових мереж та усунути їх. Виконано аналіз стану приладового обліку
кількості теплової енергії та нормативного забезпечення систем вимірювання кількості ТЕ. Встановлено, що чинні норма-
тивні документи не містять методики визначення кількості ТЕ для всіх існуючих конфігурацій систем обліку ТЕ, а також
методики оцінювання похибки (невизначеності результату вимірювання) кількості ТЕ. Розроблення таких методик є вкрай
необхідним. Виконано класифікацію систем теплопостачання, що дає змогу проаналізувати можливі схеми систем вимірю-
вання кількості. Розглянуто рівняння для визначення кількості теплової енергії для типових схем систем обліку на джерелах
ТЕ та у схемах теплопостачання споживачів. Встановлено, що у відомих нормативних документах не враховано всі особли-
вості структури систем теплопостачання споживачів, тому необхідним є подальший аналіз схем теплопостачання спожива-
чів та уточнення рівнянь для обчислення кількості ТЕ у таких системах. Сформульовано недоліки основних нормативних
документів та невирішені завдання обліку ТЕ і визначено напрями досліджень для удосконалення нормативної бази обліку
ТЕ.
Ключові слова: теплова енергія; вимірювання кількості; нормативне забезпечення; структура системи; точність вимірювання.

Вступ. Завдання економії енергоносіїв стає дедалі більш актуальним з огляду на постійне зростання їх вартості. Теплову енергію широко використовують у промисловості та житлово-комунальному господарстві України. Частка теплової енергії змінюється в межах 60-70 \% від загальної вартості послуг житлово-комунального господарства (ЖКГ), тому їі економне використання є першочерговою умовою зменшення вартості послуг ЖКГ.

Причинами неефективного використання теплової енергії $\epsilon$ :

• незадовільний технічний стан об'єктів генерації, транспортування і споживання теплової енергії;

- незадовільна система державного регулювання, яка не заохочує до ефективного використання теплової енергії;

- низький рівень обліку та регулювання теплової енергії, недосконалість нормативного забезпечення приладового обліку теплової енергії.

Зміна ситуації можлива за умови налагодження точного обліку теплової енергії на всіх ділянках іiї виробництва, транспортування та споживання, що можливо тільки за наявності якісної нормативної бази та точних технічних засобів вимірювання кількості теплової енер-

гії. Налагодження точного обліку дає змогу виявити проблемні ділянки, розробити заходи 3 реконструкції систем теплозабезпечення для підвищення їх економічної та енергетичної ефективності.

Мета роботи - проаналізувати стан обліку кількості теплової енергії, нормативного забезпечення систем вимірювання кількості тепла для виділення актуальних проблем, вирішення яких дасть змогу підвищити точність вимірювання кількості теплової енергії.

Аналіз стану нормативного забезпечення обліку кількості ТЕ. Сьогодні для організації обліку теплової енергії в нашій країні застосовують нормативні документи, зокрема документи (Zakon Ukrainy, 2017a; Proekt, 2009), які регулюють відносини, що виникають 3 огляду на виробництво, транспортування, постачання i використання теплової енергії. Облік теплової енергії здійснюють двома методами: приладовим або розрахунковим (Zakon Ukrainy, 2005, 2014, 2017a, 2017b).

Залежно від мети використання результатів вимірювання кількості ТЕ, а відповідно і від технічних, зокрема метрологічних характеристик застосованих засобів вимірювальної техніки та способів їх підтверджування,

\section{Інформація про авторів:}

Матіко Федір Дмитрович, д-р техн. наук, доцент, кафедра теплоенергетики, теплових і атомних електричних станцій. Email: fmatiko@gmail.com; http://orcid.org/0000-0001-6569-2587

Слабик Оксана Михайлівна, аспірант, кафедра автоматизації та комп'ютерно-інтегрованих технологій. Email: oksana.slabyk@ukr.net

Гутник Микола Богданович, керівник відділу енергоаудиту. Email: mbgutnyk@gmail.com

Цитування за ДСту: Матіко Ф. Д., Слабик О. М., Гутник М. Б. Аналіз нормативного забезпечення систем вимірювання кількості теплової енергії. Науковий вісник НЛтУ України. 2018, т. 28, № 3. С. 105-110.

Citation APA: Matiko, F. D., Slabyk, O. M., \& Hutnyk, M. B. (2018). Analysis of Normative Base for Systems of Measuring the Amount of Thermal Energy. Scientific Bulletin of UNFU, 28(3), 105-110. https://doi.org/10.15421/40280322 
приладові системи обліку поділяють на системи комерційного або технологічного обліку ТЕ.

Системи обліку ТЕ в науково-технічних джерелах та нормативних документах часто називають лічильниками ТЕ. Отже, як лічильник теплової енергії розглядають вимірювальний комплекс, який складається з окремих елементів, що пов'язані між собою лініями зв'язку (передачі вимірювальних сигналів). Основними конструктивними елементами лічильника ТЕ $€$ :

- обчислювач теплової енергії;

- первинні перетворювачі витрати (витратоміри, лічильники);

- вимірювальні перетворювачі температури;

- вимірювальні перетворювачі тиску.

Засоби вимірювальної техніки, які входять до складу комерційного лічильника ТЕ, мають відповідати (за їх технічними характеристиками, умовами монтажу та експлуатації) вимогам відповідних нормативних документів. Зокрема для систем вимірювання кількості теплової енергії, у складі яких застосовано витратоміри змінного перепаду тиску, вимоги щодо характеристик цих витратомірів щодо монтажу засобів вимірювання тиску, перепаду тиску, температури встановлено комплексом стандартів ДСТУ ГОСТ 8.586.1-5:2009 (DSTU HOST 8.586.1-5, 2009).

Варто зазначити, що для застосування у системах комерційного обліку ТЕ, згідно з (Zakon Ukrainy, 2005), тип лічильника ТЕ обов'язково потрібно внести до Державного реєстру затверджених типів засобів вимірювальної техніки. Його технічні характеристики повинні відповідати вимогам "Технічного регламенту засобів вимірювальної техніки" (Tekhnichnyi, 2016) та вимогам ДСТУ EN 1434:2006 (DSTU EN 1434-1, 2006; DSTU EN 1434-2, 2006; DSTU EN 1434-6, 2006). Цей комплекс стандартів встановлює вимоги до технічних та метрологічних характеристик лічильників, вимоги до їх монтажу, правила експлуатації і технічного обслуговування.

Технологічний облік ТЕ - це облік кількості ТЕ всередині підприємств. Технологічний облік ТЕ не $є$ підставою для комерційних розрахунків, тому згідно із Законом України "Про метрологію та метрологічну діяльність" (Zakon Ukrainy, 2014) оцінку відповідності засобів технологічного обліку (засобів вимірювальної техніки, які не застосовують у сфері законодавчо регульованої метрології) проводять на добровільних засадах.

Облік теплової енергії в Україні виконують згідно з "Правилами обліку, відпуску і споживання теплової енергіï" (Proekt, 2009; Metodika, 2014), які визначають основні технічні, організаційні та процедурні вимоги до здійснення обліку теплової енергії та теплоносія на джерелах теплопостачання і у споживачів теплової енергії у водяних системах теплопостачання і теплоспоживання, зокрема:

- встановлюють основні вимоги до методик виконання вимірювань теплової енергії і маси теплоносія засобами вимірювальної техніки на джерелах теплової енергії та у споживачів водяних і парових систем теплопостачання;

- визначають основні вимоги до приладів обліку теплової енергії, маси теплоносія та його параметрів;

- встановлюють правила влаштування і введення в експлуатацію вузла обліку теплової енергії.

Однак, цей надзвичайно важливий документ дотепер належно не затверджено. Тобто облік ТЕ в Україні ведуть на основі не затвердженого проекту "Правил ..." (KTM 204-Ukrainy 244-94, 2001; Proekt, 2009), що приз- водить до сумнівних результатів обліку ТЕ 3 погляду законодавчо-регульованої метрології.

Отже, результати виконаного аналізу нормативної бази обліку теплової енергії свідчать про те, що сьогодні в Україні відсутній нормативний документ щодо організації обліку кількості ТЕ. Наявний проект "Правил обліку, відпуску і споживання теплової енергії" (DBN V.2.5-9, 2008; Proekt, 2009) не містить методики визначення кількості ТЕ для всіх чинних конфігурацій систем обліку ТЕ, а також методики оцінювання похибки (невизначеності результату вимірювання) кількості ТЕ. Згідно з вимогами Закону України "Про метрологію та метрологічну діяльність" (DSTU 3339-96, 2005), результати вимірювань можуть бути використані у сфері законодавчо регульованої метрології тільки за умови, що для таких результатів відомі відповідні характеристики похибок або невизначеність вимірювань, тому розроблення таких методик є вкрай необхідним.

Виклад основного матеріалу. Існує два види систем теплопостачання - централізована і децентралізована. Системи централізованого теплопостачання мають такі переваги:

- такий варіант обігріву приміщення коштує значно дешевше від автономного, тому що не потрібно купувати дорогі прилади, які генерують тепло, а також самостійно виконувати монтажні роботи;

- більшість котелень оснащено приладами, здатними працювати практично на будь-якому виді палива, що позитивно позначається на надійності такого варіанта опалення та економічності системи;

- окрім цього, такий спосіб нагріву $є$ екологічно чистим для споживача, оскільки в житлові чи громадські приміщення не проникає ніяких шкідливих продуктів згоряння, чого не скажеш про деякі автономні системи опалення.

Однак, недоліки у такого способу теплопостачання також $\epsilon$, і найбільш істотні серед них - це значні втрати тепла в таких системах, складність регулювання температури у споживачів, а також необхідність обліку кількості ТЕ в кожного споживача.

Щодо систем децентралізованого теплопостачання, то їх основною перевагою є зменшення втрат у теплових мережах.

3 огляду на зазначені вище переваги та недоліки централізованих систем теплопостачання очевидно, що в таких системах необхідно забезпечувати точний облік кількості теплової енергії, яку розподіляють споживачам. Тільки в такий спосіб можна звести баланс кількості теплової енергії, відпущеної 3 джерел генерації тепла, та теплової енергії, розподіленої споживачам, а також визначити втрати енергії в теплових мережах.

В автономних системах внутрішнього теплопостачання, у яких джерело теплової енергії наявне в кожного споживача, засоби обліку теплової енергії зазвичай не встановлюють. Однак, для об'єктів обладнаних індивідуальним тепловим пунктом (наприклад, багатоквартирні будинки) встановлення засобів обліку для окремих споживачів також є доцільним.

Системи теплопостачання (теплопостачання і теплоспоживання) за видом теплоносія поділяють на водяні та парові. Водяні системи теплопостачання застосовують для задоволення потреб споживачів щодо забезпечення санітарно-гігієнічних вимог внутрішньої температури в приміщеннях, вентиляції і гарячого водопостачання, а парові системи - для забезпечення технологічних потреб промислових підприємств. 
Вид теплоносія визначає деякі характеристики системи, зокрема: тип та характеристики витратоміра, алгоритми розрахунку властивостей теплоносія, що необхідно врахувати під час розроблення систем обліку кількості теплової енергії. Зокрема за методом вимірювання витрати теплоносія, який визначає область застосування і метрологічні характеристики первинних перетворювачів витрати, теплові лічильники поділяють на: змінного перепаду тиску, тахометричні, вихрові, електромагнітні, ультразвукові.

За кількістю паралельно прокладених трубопроводів системи теплопостачання поділяють на одно-, дво- і багатотрубні. За наявністю відборів мережної води: закриті - без відборів мережної води; відкриті - $з$ відборами. За характером приєднання до теплової мережі системи теплоспоживання бувають двох видів: залежні - в яких теплоносій із теплової мережі подають безпосередньо в систему теплоспоживання; незалежні - теплоносій із теплової мережі нагріває через теплообмінник вторинний теплоносій, який подають у систему теплоспоживання.

Структура системи обліку теплової енергії, а також рівняння визначення кількості теплової енергії залежать від виду системи теплопостачання (теплоспоживання). Враховуючи сформовану вище класифікацію системи теплопостачання (теплоспоживання), розглянемо докладніше облік теплової енергії у системах різних видів.

Проаналізуємо структуру систем приладового обліку теплової енергії на основних елементах централізованого теплопостачання, а саме: а) на виході джерела теплопостачання; б) у точках передавання теплової енергї безпосереднім споживачам.

Кількість теплової енергії, яка переноситься потоком теплоносія у трубопроводі за певний проміжок часу, визначають за формулою

$$
W=\int_{t_{0}}^{t k} Q \cdot h d t,
$$

де: $Q$ - витрата теплоносія; $h$ - питома ентальпія теплоносія, яка є функцією його параметрів (тиску та температури), $h=f(T, P) ; t_{0}$ - момент часу, що відповідає початку вимірювань теплової енергії; $t_{k}$ - момент часу, що відповідає закінченню інтервалу часу вимірювань теплової енергії.

Однак, на практиці необхідно визначати не загальну кількість енергії, яку переносить потік теплоносія, а кількість, яку було відібрано від цього потоку. Зокрема для системи теплопостачання 3 одним подавальним та одним зворотним трубопроводом, кількість теплової енергії, яку відібрав споживач, визначають за формулою

$$
W=\int_{t_{0}}^{t k} Q_{1} \cdot h_{1} d t-\int_{t_{0}}^{t k} Q_{2} \cdot h_{2} d t,
$$

де, окрім позначень застосованих у формулі (1), маємо: $Q_{1}, Q_{2}$ - витрата теплоносія в подавальному та зворотному трубопроводі; $h_{1}$ - питома ентальпія теплоносія в подавальному трубопроводі, $h_{1}=f\left(T_{n p}, P_{n p}\right) ; h_{2}$ - питома ентальпія теплоносія у зворотному трубопроводі, $h_{2}=$ $f\left(T_{3 в}, P_{38}\right)$. Тут розглядаємо систему теплопостачання, в якій витрата теплоносія у зворотному трубопроводі 3 різних причин відрізняється від витрати у подавальному трубопроводі.
Отже, для точного вимірювання кількості енергії, що відібрано з такої системи теплопостачання, необхідно виміряти витрату теплоносія, його тиск та температуру в кожному 3 трубопроводів. У такому випадку потрібно застосувати велику кількість приладів, що істотно збільшує вартість системи вимірювання кількості теплової енергії (СВК ТЕ), а також вартість її обслуговування. Тому під час розроблення СВК ТЕ для конкретних технологічних умов намагаються спростити їх структуру та зменшити кількість застосованих засобів вимірювання, погоджуючись на деяке підвищення похибки вимірювання кількості теплової енергії. Відомо такі реалізації спрощених СВК ТЕ:

Витрати теплоносія в подавальному та зворотному трубопроводах рівні, $Q_{1}=Q_{2}$ (для закритих систем):

$$
W=\int_{t_{0}}^{t_{k}} Q \cdot\left(h_{1}-h_{2}\right) d t .
$$

У таких системах застосовують один витратомір та вимірювальні перетворювачі тиску і температури в подавальному та зворотному трубопроводах.

Витрати теплоносія в подавальному та зворотному трубопроводі рівні, тиск у подавальному та зворотному трубопроводах постійний $h_{1}=f\left(T_{n p}, P_{1 \text { const }}\right), h_{2}=f\left(T_{36}\right.$, $\left.P_{2 \text { const }}\right)$.

$$
W=\int_{t_{0}}^{t k} Q \cdot\left(h_{1}\left(T_{n p}, P_{\text {const }}\right)-h_{2}\left(T_{36}, P_{2 \text { const }}\right)\right) d t .
$$

У таких системах застосовують один витратомір та вимірювальні перетворювачі температури в подавальному та зворотному трубопроводах. За такою структурою побудовано більшість систем обліку ТЕ невеликих споживачів.

Кількість теплової енергії $W$, відпущеної джерелом ТЕ в двотрубну магістраль водяної теплової мережі (рис. 2), залежно від розміщення витратоміра обчислюють за такими формулами (Metodika, 2014):

a) під час використання витратомірів на подавальному та підживлювальному трубопроводах:

$$
W=\int_{t_{0}}^{t k} Q_{1} \cdot\left(h_{1}-h_{2}\right) d t+\int_{t_{0}}^{t k} Q_{n} \cdot\left(h_{2}-h_{\mathrm{xв}}\right) d t,
$$

де: $Q_{1}$ - масова витрата теплоносія у подавальному трубопроводі; $Q_{n}$ - масова витрата теплоносія, використаного на підживлення системи теплопостачання; $h_{1}-$ питома ентальпія теплоносія у подавальному трубопроводі; $h_{2}$ - питома ентальпія теплоносія у зворотному трубопроводі; $h_{x в}-$ питома ентальпія холодної води;

б) під час використання витратомірів на зворотному та підживлювальному трубопроводах:

$$
W=\int_{t_{0}}^{t_{k}} Q_{2} \cdot\left(h_{1}-h_{2}\right) d t+\int_{t_{0}}^{t k} Q_{n} \cdot\left(h_{1}-h_{\text {хв }}\right) d t,
$$

де: $Q_{2}$ - масова витрата теплоносія у зворотному трубопроводі;

в) під час використання витратомірів на подавальному та зворотному трубопроводі:

$$
W=\int_{t_{0}}^{t_{k}} Q_{1} \cdot\left(h_{1}-h_{x b}\right) d t+\int_{t_{0}}^{t_{k}} Q_{2} \cdot\left(h_{2}-h_{\mathrm{xB}}\right) d t .
$$

У загальному випадку на джерелі ТЕ може бути різна кількість подавальних, зворотних трубопроводів, а також трубопроводів підживлення із різних джерел. Система обліку ТЕ повинна враховувати всі потоки 
теплоносія. Для такого загального випадку, рівняння обчислення кількості ТЕ має такий вигляд:

$$
W=\sum_{i=1}^{a} \int_{t_{0}}^{t / k} Q_{1 i} \cdot \mathrm{h}_{1 \mathrm{i}} d t-\sum_{j=1}^{b} \int_{t_{0}}^{t / k} Q_{2 j} \cdot \mathrm{h}_{2 \mathrm{j}} d t-\sum_{p=1}^{m} \int_{t_{0}}^{t / k} Q_{\text {пр }} \cdot \mathrm{h}_{\text {хвр }} d t,
$$

де: $a$ - кількість подавальних трубопроводів; $b$ - кількість зворотних трубопроводів; $m$ - кількість вузлів обліку на підживлювальних трубопроводах; $Q_{n p}$ - масова витрата теплоносія, використаного для підживлення системи за кожним підживлювальним трубопроводом.

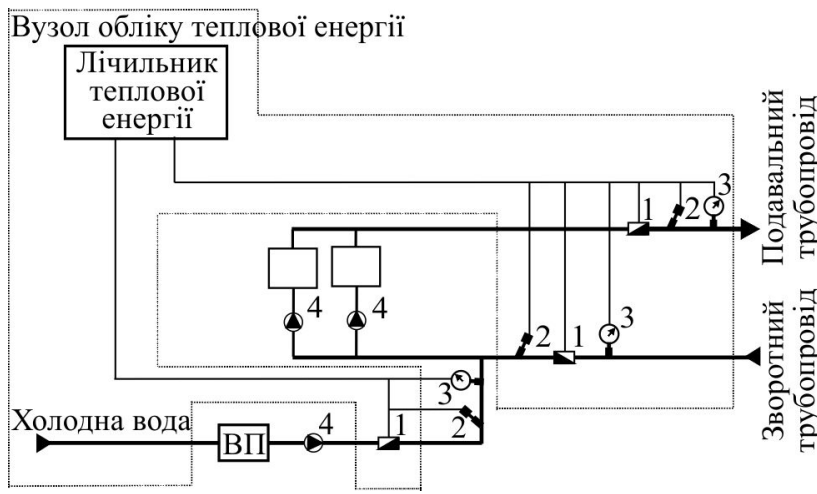

Рис. 2. Схема розташування точок вимірювання кількості теплової енергії і масової витрати теплоносія, а також параметрів теплоносія, які реєструються на джерелі теплової енергії для водяних систем теплопостачання: 1) первинний перетворювач витрати; 2) термоперетворювач; 3) давач тиску; 4) насос

Формули (5)-(8) дають змогу реалізувати обчислення кількості ТЕ для різних структур систем обліку кількості ТЕ, що трапляється на практиці експлуатації об'єктів генерування ТЕ.
Облік ТЕ у споживачів. Системи обліку ТЕ у споживачів (для закритих систем теплопостачання) повинні реєструвати за годину, добу або звітний період кількість отриманої теплової енергії, а також такі параметри: масову витрату теплоносія в подавальному трубопроводі, масову витрату теплоносія у зворотному трубопроводі (в разі установки другого витратоміра), середнє значення температури та тиску теплоносія, масову витрату теплоносія, використаного на підживлення, час роботи лічильника теплової енергії у штатному і позаштатному режимах (рис. 3).

Кількість теплової енергії, отриманої споживачем за звітний період, для незалежної системи теплопостачання визначають за формулою [16]

$$
W=W_{\text {вим }} \pm W_{\text {тп }}+W_{\text {сп }}+\int_{t_{0}}^{t_{k}} Q_{n} \cdot\left(h_{2}-h_{\text {вв }}\right) d t,
$$

де: $W_{\text {вим }}$ - виміряна тепловим лічильником кількість теплової енергії; $W_{\text {тп }}$ - кількість теплової енергії, витраченої на компенсацію втрат теплової енергії з урахуванням витоку теплоносія на ділянці трубопроводу від границі балансової належності до вузла обліку. У разі установки вузла обліку до границі балансової належності $\left(Q_{\text {тп }}\right)$ беруться зі знаком "-", якщо після границі балансової належності, то - зі знаком "+"; $W_{\text {сп }}$ кількість теплової енергії, витраченої споживачем за час дії нештатних ситуацій за показниками приладів обліку; $Q_{\text {п }}$ масова витрата теплоносія, витраченого споживачем на підживлення систем опалення, яку може бути визначено за показами лічильника води.

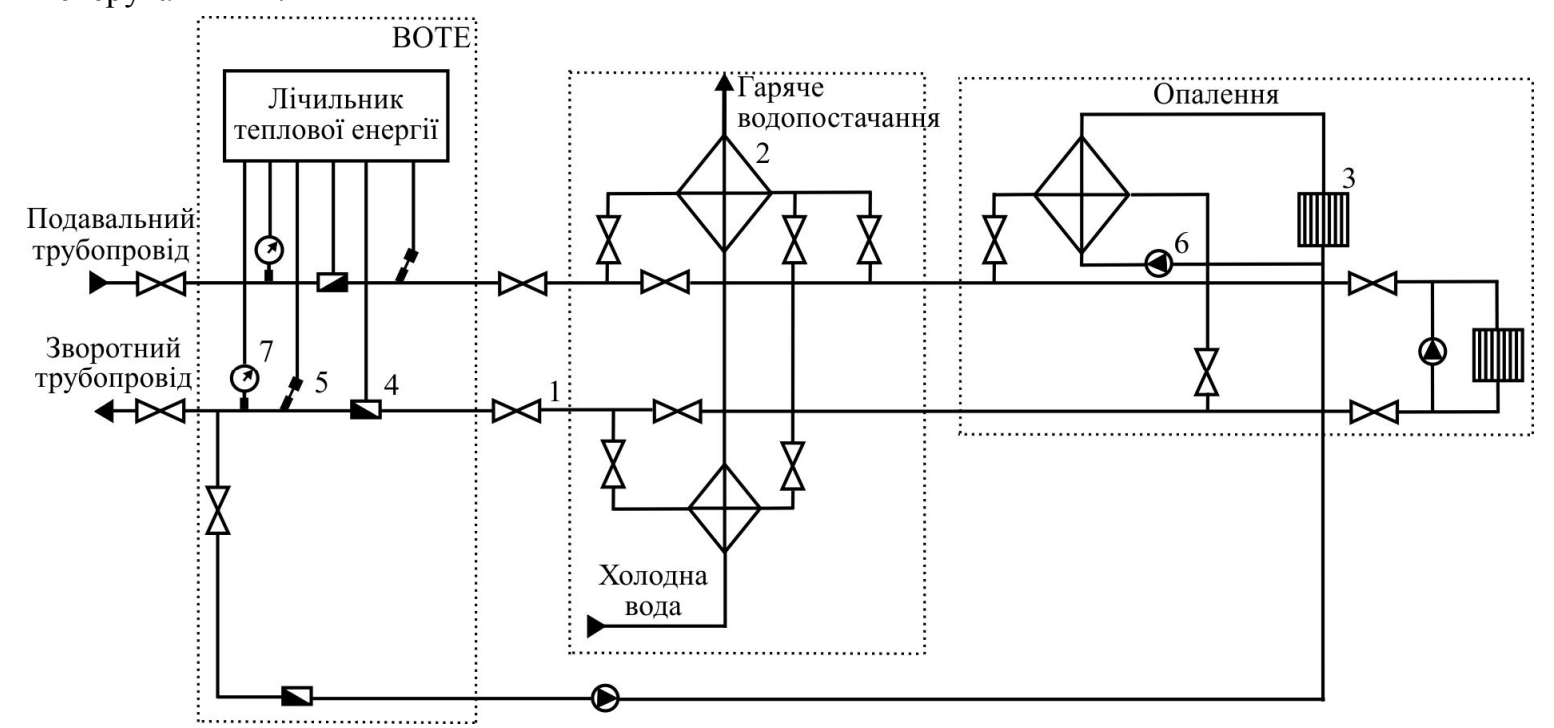

Рис. 3. Схема розміщення точок вимірювання кількості теплової енергії та масової витрати теплоносія, а також параметрів теплоносія, які реєструються в закритих системах теплопостачання на теплових пунктах із додатковим контролем витрати теплоносія у зворотному трубопроводі: 1) запірна арматура; 2) теплообмінник; 3) опалювальний прилад; 4) первинний перетворювач витрати; 5) термоперетворювач; 6) насос; 7) давач тиску

За незалежної схеми підключення систем опалення додатково реєструють масу теплоносія, витраченого на підживлення незалежного контуру. Кількість ТЕ ( $\left.W_{\text {вим }}\right)$, виміряної тепловим лічильником, можна обчислити за формулою (3).

Кількість теплової енергії, отриманої споживачем за звітний період, для залежної системи теплопостачання визначають за формулою, аналогічною формулі (9), за винятком того, що замість витрати теплоносія на підживлення $Q_{n}$ вводять масову витрату витоків теплоносія у теплоспоживаючих установках $Q_{b}$. Оскільки вит- рату витоків виміряти неможливо, то її величину визначають на основі досвіду експлуатації теплової мережі.

Системи обліку ТЕ у споживачів для відкритих систем (рис. 4) мають реєструвати за кожну годину, добу або звітний період кількість отриманої теплової енергії, а також такі параметри: масову витрату теплоносія в подавальному трубопроводі, масову витрату теплоносія у зворотному трубопроводі, середньозважене значення температури теплоносія, середнє значення тиску теплоносія, масу теплоносія, використаного на підживлення, 
час роботи лічильника теплової енергії у штатному і позаштатному режимах.

Додатково в системі гарячого водопостачання реєструють такі параметри (див. рис. 4):

a) витрата, тиск і температура гарячої води;

б) витрата, тиск і температура циркуляційної води (теплоносія).

Кількість теплової енергії, отриманої споживачем у відкритій системі теплопостачання, за звітний період визначають за формулою, аналогічною формулі (9) (Metodika, 2014). Кількість теплової енергії ( $\left.W_{\text {вим}}\right)$, виміряної тепловим лічильником, можна обчислити за формулою (7).

Масу теплоносія, використаного у відкритій системі, за звітний період визначають за формулами (Pravyla, 2007; Metodika, 2014):

$$
\begin{gathered}
M=M_{u}+M_{6}+M_{H c}, \\
M_{u}=M_{1}-M_{2},
\end{gathered}
$$

де: $M_{\text {в }}$ маса теплоносія, втраченого в процесі передачі теплової енергії через нещільності в арматурі та тру- бопроводах теплових мереж, т; $M_{\text {ш }}$ - маса використаного теплоносія, виміряна тепловим лічильником під час його роботи у штатному режимі, т; $M_{\text {нс }}$ - маса теплоносія, використаного за період нештатних ситуацій, т.

Результати аналізу літературних джерел, зокрема наявних нормативних документів, свідчать про те, що в них не враховано всі особливості структури систем теплопостачання споживачів. Тому необхідним є подальший аналіз схем теплопостачання споживачів та уточнення рівнянь для обчислення кількості ТЕ у таких системах.

Розрахунковий метод визначення кількості ТЕ застосовують за відсутності засобів обліку теплової енергії як на джерелах генерації тепла (котельні, ТЕЦ), так і у споживачів (теплові вводи будівель усіх типів житлові, громадські тощо). Основним нормативним документом для розрахунку кількості теплової енергії, який використовують теплопостачальні організації, є КТМ 204-України 244-94 (Pravyla, 2005; KTM 204-Ukrainy 244-94, 2001).

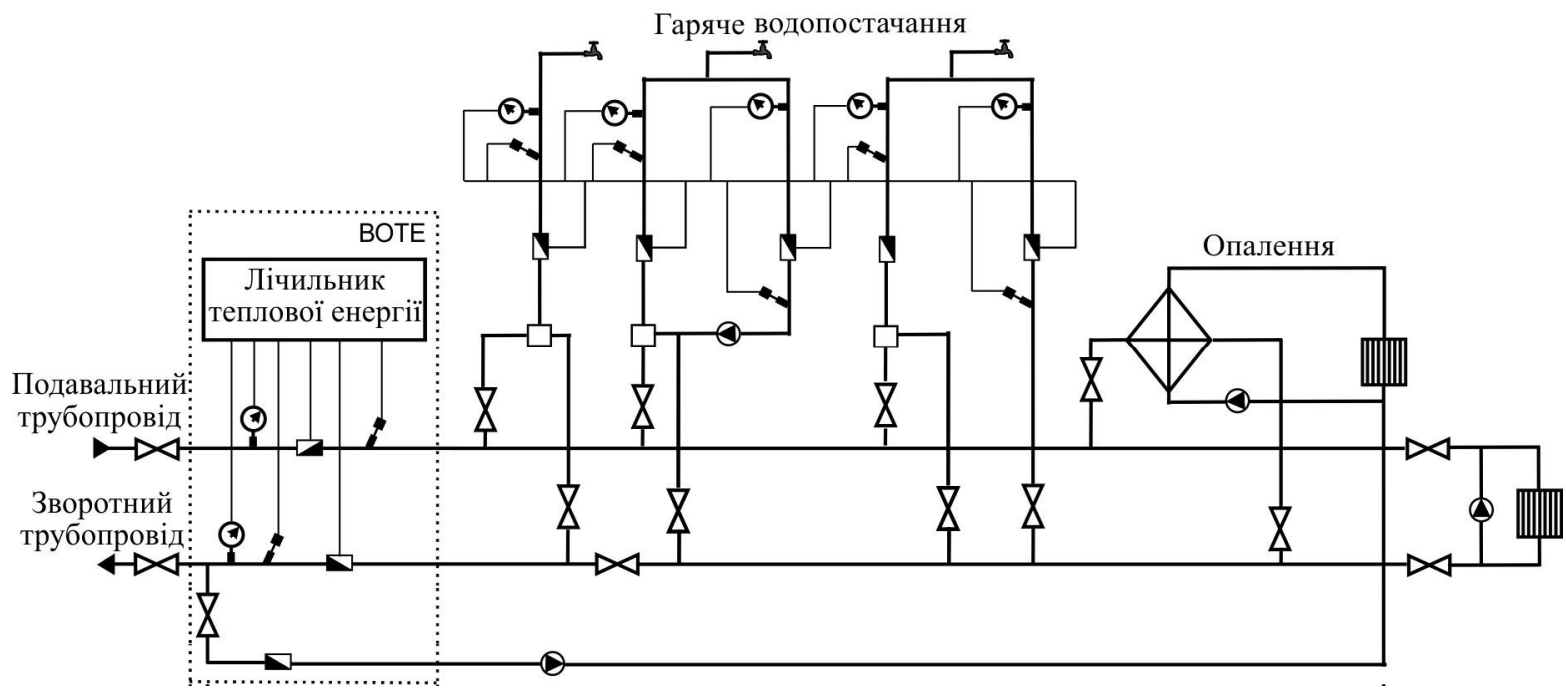

Рис. 4. Схема розміщення точок вимірювання кількості теплової енергії та масової витрати теплоносія, а також параметрів теплоносія, які реєструють у відкритих системах теплопостачання

У розрахунковому методі при обліку ТЕ на джерелах генерації тепла важливими параметрами під час розрахунків $\epsilon$ :

1. Нижча теплотворна здатність палива, яке використовують у котельні.

2. Облікована кількість використаного палива.

3. ККД котельних агрегатів.

4. Технологічні втрати ТЕ на власні потреби.

Очевидно, що такі параметри, як ККД котлів, обсяги технологічних втрат ТЕ не можна визначити з високою точністю. Тому результат розрахункового визначення кількості продукованої ТЕ також буде мати невисоку точність, а отже, для підвищення точності обліку ТЕ необхідне впровадження приладових систем вимірювання кількості ТЕ у всіх точках постачання (споживання) ТЕ.

Висновки. За результатами виконаного аналізу можна зробити такі висновки:

- на сьогодні в Україні немає затвердженої у встановленому порядку методики визначення кількості TЕ; у проекті "Правил обліку..." (Zakon Ukrainy, 2017b; DSTU 3339-96, 2005; Proekt, 2009) не враховано деякі конфігурації чинних систем обліку TE;

- у жодному з відомих джерел немає методики оцінювання похибки (невизначеності результату вимірювання) кількос- ті ТЕ. Згідно з вимогами Закону України "Про метрологію та метрологічну діяльність" результати вимірювань можна використати у сфері законодавчо регульованої метрології тільки за умови, що для таких результатів відомі відповідні характеристики похибок або невизначеність вимірювань, тому розроблення таких методик $\epsilon$ вкрай потрібним;

- у відомих джерелах представлені залежності, які дають змогу реалізувати обчислення кількості ТЕ для різних структур систем обліку кількості ТЕ, що трапляються на практиці експлуатації об'єктів генерування ТЕ; однак у цих джерелах не враховано всі особливості структури систем теплопостачання споживачів, тому необхідним $є$ подальший аналіз схем теплопостачання споживачів та уточнення рівнянь для обчислення кількості ТЕ у таких системах;

- у нормативних документах не відтворено особливості структури систем вимірювання кількості ТЕ, у яких застосовано витратоміри на основі стандартних звужувальних пристроїв.

\section{Перелік використаних джерел}

DBN V.2.5-39:2008. Teplovi merezhi. Minrehionbud Ukrainy. Kyiv. DSTU 3339-96: 2005. Teplolichylnyky. Zahalni tekhnichni vymohy DSTU EN 1434-1:2006. Teplolichylnyky. Chastyna 1. Zahalni vymohy

DSTU EN 1434-2:2006. Teplolichylnyky. Chastyna 2. Vymohy do konstruktsii 
DSTU EN 1434-6:2006. Teplolichylnyky. Chastyna 6. Montazh, uvedennia $\mathrm{v}$ ekspluatatsiiu, kontrol $\mathrm{v}$ ekspluatatsii y tekhnichne obsluhovuvannia.

DSTU HOST 8.586.1-5:2009. (ISO 5167-1:2003.). Metrolohiia. Vymiriuvannia vytraty ta kilkosti ridyny y hazu iz zastosuvanniam standartnykh zvuzhuvalnykh prystroiv.

KTM 204-Ukrainy 244-94. (2001). Derzhavnyi komitet Ukrainy po zhytlovo-komunalnomu hospodarstvu. Kyiv.

Metodika. (2014). Metodika osushchestvleniia kommercheskogo ucheta teplovoi energii, teplonositelia. Utverzhdena prikazom Ministerstva stroitelstva i zhilishchno-kommunalnogo khoziaistva RF ot 17 marta 2014 g., N99/pr.

Pravyla. (2005). Pravyla nadannia posluh $\mathrm{z}$ tsentralizovanoho opalennia, postachannia kholodnoi ta hariachoi vody ta vodovidvedennia (zatverdzheni postanovoiu Kabinetu Ministriv Ukrainy vid 21.07.2005 ya., № 630). [In Ukrainian].
Pravyla. (2007). Pravyla korystuvannia teplovoiu enerhiieiu (zatverdzheni postanovoiu Kabinetu Ministriv Ukrainy vid 03.10.2007 уа., № 1198)

Proekt. (2009). Ministerstvo z pytan zhytlovo-komunalnoho hospodarstva Ukrainy. Pravyla obliku, vidpusku i spozhyvannia teplovoi enerhii. Kyiv.

Tekhnichnyi. (2016). Tekhnichnyi rehlament zasobiv vymiriuvalnoi tekhniky (zatverdzheni postanovoiu Kabinetu Ministriv Ukrainy vid 24.02.2016 ya., № 163)

Zakon Ukrainy. (2005). "Pro teplopostachannia" vid 02.06.2005 ya., № 2633-IV. [In Ukrainian].

Zakon Ukrainy. (2014). "Pro metrolohiiu ta metrolohichnu diialnist" vid05.06.2014 ya., № 1314-VII. [In Ukrainian].

Zakon Ukrainy. (2017a). "Pro komertsiinyi oblik teplovoi enerhii ta vodopostachannia" vid 09.11.2017 ya., № 2189-VIII. [In Ukrainian].

Zakon Ukrainy. (2017b). "Pro zhytlovo-komunalni posluhy" vid 09.11.2017 ya., № 2189-VIII. [In Ukrainian].

Ф. Д. Матико 1 , О. М. Слабик', М. Б. Гутник 2

${ }^{1}$ Национальный университет "Львовская политехника", г. Львов, Украина

2 Частное акиионерное общество "Институт энергоаудита и учета энергоносителей", г. Львов, Украина

\section{АНАЛИЗ НОРМАТИВНОГО ОБЕСПЕЧЕНИЯ СИСТЕМ ИЗМЕРЕНИЯ КОЛИЧЕСТВА ТЕПЛОВОЙ ЭНЕРГИИ}

Тепловую энергию широко используют в промышленности и жилищно-коммунальном хозяйстве Украины. Налаживание точного учета тепловой энергии (ТЭ) необходимо для ее эффективного и экономного использования, а также дает возможность выявить недостатки теплогенерирующих объектов и тепловых сетей и устранить их. Выполнен анализ состояния приборного учета количества тепловой энергии и нормативного обеспечения систем измерения количества ТЭ. Установлено, что действующие нормативные документы не содержат методики определения количества ТЭ для всех существующих конфигураций систем учета ТЭ, а также методики оценки погрешности (неопределенности результата измерения) количества ТЭ. Разработка таких методик является крайне необходимой. Выполненная классификация систем теплоснабжения позволяет проанализировать возможные схемы систем измерения количества. Рассмотрены уравнения для определения количества тепловой энергии для типовых схем систем учета на источниках ТЭ и в схемах теплоснабжения потребителей. Установлено, что в известных нормативных документах не учтены все особенности структуры систем теплоснабжения потребителей, поэтому необходим дальнейший анализ схем теплоснабжения потребителей и уточнение уравнений для вычисления количества ТЭ в таких системах. Сформулированы недостатки основных нормативных документов и нерешенные задачи учета ТЭ, определены направления исследований для совершенствования нормативной базы учета ТЭ.

Ключевые слова: тепловая энергия; измерение количества; нормативное обеспечение; структура системы; точность измерения.

F. D. Matiko' , O. M. Slabyk1, M. B. Hutnyk ${ }^{2}$

${ }^{1}$ Lviv Polytechnic National University, Lviv, Ukraine

${ }^{2}$ Private joint-stock company "Institute of Energy Audit and Energy Carrier Accounting", Lviv, Ukraine

The paper is devoted to the organization of thermal energy metering in Ukraine. The main attention is paid to the analysis of normative documents and existing methods for calculating the amount of thermal energy, which is the basis for custody transfer metering. The custody transfer metering of thermal energy is organized in order to make calculations between the heat supplying organizations and consumers of thermal energy; for controlling the efficient use of thermal energy, heat carrier; for controlling the thermal and hydraulic operating modes of heat supplying systems and heat consumption. Therefore, the authors present a classification of the heat supplying systems, which enables analysing the possible schemes of systems for measuring the amount of thermal energy. The equations for determining the amount of thermal energy for typical schemes of metering systems at heat energy sources and in heat supplying schemes for consumers are considered. Considering the importance and complexity of methods for determining the amount of thermal energy in heat supplying systems, the authors highlight the main shortcomings of the actual normative documents, in particular, the lack of the approved technique for determining the amount of thermal energy; the lack of the technique for assessment of the error (uncertainty) of the result of thermal energy amount measurement; the features of the structure of the systems for measuring the amount of thermal energy based on the differential pressure flowmeters are not presented in the normative documents. To conclude, establishment of accurate metering of thermal energy at heat generating plants and consumers of thermal energy will allow identifying the problematic areas, developing the measures for reconstruction of heat supplying systems in order to increase their economic and energy efficiency. Implementation of such metering is possible only if there is a qualitative normative base and accurate instruments (devices) for measuring the amount of thermal energy.

Keywords: thermal energy; quantity measurement; normative base; system structure; measurement accuracy. 